\title{
DESCRIPTION OF A NEW SPECIES OF AGAMID LIZARD FROM THE MALAY PENINSULA.
}

\author{
By Doris M. Cochran,
} Aid, Division of Reptiles and Batrachians.

The species described below introduces apparently for the first time to the Malay Peninsula fauna a member of the group of the genus Gonocephalus represented by the type species Gonocephalus chamaeleontinus. This group, which is characterized by the supraciliary border being strongly raised and forming an angular projection posteriorly, has hitherto been known only from species occurring in Java, Borneo, Sumatra, and some of the adjacent smaller islands; The interesting point is that the new species seems to be more closely allied to the Bornean Gonocephalus doriae than to the JavaSumatran Gonocephalus chamaeleontinus.

\section{GONOCEPHALUS ABBOTTI, new species.}

Diagnosis.-Supraciliary border strongly raised, forming an angular projection posteriorly; no enlarged scales on sides of back or on temporal region; scales of row next to median series of enlarged nuchal and dorsal crest-scales large, flat, without keel or spine; dorsal crest continuous with and lower than nuchal; third and fourth fingers of equal length.

Description.-Adult female, U.S.N.M. No. 24028; Trang, Lower Siam; Dr. W. L. Abbott, collector.

Head high, with strongly elevated supraciliary borders forming an angle posteriorly; snout as long as the diameter of orbit, ending in a pronounced rounded hump; no indication of supraorbital semicircles; scales between eyes and on snout only slightly smaller than those of supraorbital region; a few large, perfectly flat median scales on top of snout; tympanum smaller than eye-opening; sides of head covered with smooth scales about as large as the average dorsals; no enlarged scales on temples or body; 12 upper and 13 lower labials; gular sac well developed, with serrated anterior edge; gular scales much smaller than ventrals, smooth; body very strongly compressed; nuchal crest beginning on occiput; nuchal and dorsal crests perfectly continuous, gradually decreasing in height from above tympanum to the tail; no depression in the crest above shoulders; crest-scales smooth, triangular, nearly as wide as high, nuchals convex on front, concave behind; first (upper) row of scales covering base of crest composed of irregularly pentagonal flat scales as large

No. 2421. Proceedings U. S. National Museum, Vol. 60, Art. 26. 
as those of the median row, without spine or keel; second and third basal rows smaller, smooth, polygonal; nuchal crest measured from lower edge of third basal row equals distance from orbit to halfway between nostril and tip of snout; dorsal scales small, smooth, not pointed, scarcely imbricate, without any appreciably enlarged ones; ventral scales much larger, smooth; limbs above with subequal smooth scales; third and fourth fingers equal; the adpressed hind limb reaches the orbit; tail without crest, strongly compressed, with keeled, slightly serrated upper edge; upper caudals smooth, lower ones larger and strongly keeled; length of tail not quite twice that head and body. Color (in alcohol) greenish above, with dark longitudinal reticulations; tail with regular dark annuli.

\section{Dimensions.}

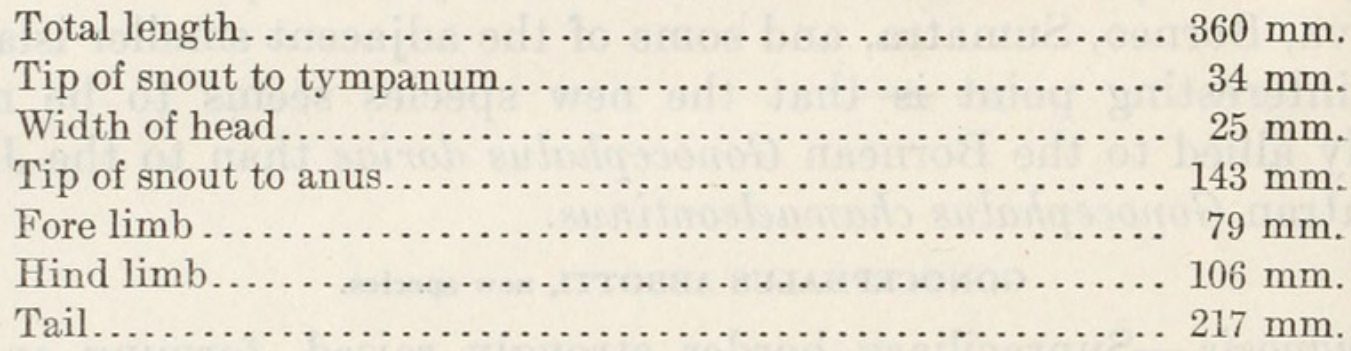

Remarks.-In comparing this specimen with adult females of Gonocephalus chamaeleontinus from Sumatra, I find that the latter differ from it in several striking characteristics:

1. The female $G$. chamaeleontinus has the dorsal and nuchal crests formed of comparatively long and sharply pointed lanceolate spines. The highest nuchal spines are about three times as high as their greatest width. The upper outline of the crest when viewed in profile shows a maximum elevation just back of the tympanum, with a sudden lowering in height above the shoulders, from which point the dorsal crest continues to decrease regularly in height. In the male $G$. chamaeleontinus there is a slight increase in the height of the dorsal crest for a few scales behind the depression, after which the dorsals decrease regularly. The crest of $G$. abbotti does not have any depression above the shoulders; but lessens gradually from above the tympanum to the tail. The first row of scales at the base of the median series forming the crest is mush larger in G. abbotti, being approximately of the same size as the median series of the crest. In $G$. abbotti these scales are flat, smooth, without keels or spines, while in $G$. chamaeleontinus they have a spine on the upper margin and are distinctly keeled.

2. The new species has no enlarged scales on the sides of the head. In $G$. chamaeleontinus the large conical scales above and below the tympanum are a prominent feature. There is a series of 8 or 9 enlarged tubercular scales on the sides of the body in G. chamaeleontinus. These are from three to six times the diameter of the sur- 
rounding scales. In $G$. abbotti there are no enlarged scales on the sides, unless two or three slightly larger scales on the left side may be so interpreted.

3. In all the specimens of $G$. chamaeleontinus at hand there is a distinct trace of the supraorbital semicircle, appearing as a row of 4 slightly elevated scales. Between these two low ridges the scales are very small, almost granular. In $G$. abbotti there is not the slightest trace of supraorbital semicircles, and the scales of the interorbital region are not noticeably smaller than those elsewhere on top of the head.

4. In the new species the third and fourth fingers are of equal length, while in $G$. chamaeleontinus the fourth finger is slightly longer than the third.

In comparing Gonocephalus abbotti with Gonocephalus doriae Peters the resemblance is found to be much more close.

Thus the new species agrees with $G$. doriae in lacking the scattered enlarged scales on the back and the tubercles on the temporal region; in having the scales next to the nuchal and dorsal crest-spines large and flat, without keel or spine; and in having the third and fourth fingers of equal length, points which, as shown above, distinguish it from $G$. chamaeleontinus. On the other hand, it differs essentially from $G$. doriae in the dorsal crest, which, instead of being "almost as high as the nuchal," is much lower and gradually diminishing from where it joins the nuchal. The type and only specimen is a female, and the crests are probably not developed to the same extent as in the male, but judging from the differences between the males and females in $G$. chamaeleontinus the median spines of the crests probably never reach a development equaling that shown in the latter species.

The new species is named for its discoverer, Dr. W. L. Abbott.

3136-22-Proc.N.M.Vol.60-47 


\section{$2 \mathrm{BHL}$ Biodiversity Heritage Library}

Cochran, Doris M. 1922. "Description of a new species of agamid lizard from the Malay Peninsula." Proceedings of the United States National Museum 60(2421), 1-3. https://doi.org/10.5479/si.00963801.60-2421.1.

View This Item Online: https://www.biodiversitylibrary.org/item/32390

DOI: https://doi.org/10.5479/si.00963801.60-2421.1

Permalink: https://www.biodiversitylibrary.org/partpdf/11693

\section{Holding Institution}

Smithsonian Libraries

\section{Sponsored by}

Smithsonian

\section{Copyright \& Reuse}

Copyright Status: NOT_IN_COPYRIGHT

This document was created from content at the Biodiversity Heritage Library, the world's largest open access digital library for biodiversity literature and archives. Visit BHL at https://www.biodiversitylibrary.org. 